\title{
The Effect of Socio-Scientific Argumentation Method on Students' Entrepreneurship Perceptions
}

\author{
Erkan Özcan* \\ Dokuz Eylül University, Buca Faculty of Education, Science Education Department, \\ ORCID: 0000-0002-8579-6233
}

\author{
Ali Günay Balım \\ Dokuz Eylül University, Buca Faculty of Education, Science Education Department, \\ ORCID: 0000-0003-2010-1696
}

\begin{tabular}{|c|c|}
\hline \multirow{2}{*}{$\begin{array}{l}\text { Article history } \\
\text { Received: } \\
09.05 .2020\end{array}$} & \multirow{11}{*}{$\begin{array}{l}\text { Aim of this research is to examine the effect of the use of the socio- } \\
\text { scientific argumentation method on students' entrepreneurial } \\
\text { perceptions in the middle school science course. In the study, quasi- } \\
\text { experimental design with pretest-posttest control group, as one of } \\
\text { the quantitative research, was used. Experiment and control groups } \\
\text { were formed from students who were studying in four classes in a } \\
\text { determined middle school in the } 2017-2018 \text { academic year. In this } \\
\text { study, lessons were taught with the socio-scientific argumentation } \\
\text { method in the experiment group while Turkish Science Education } \\
\text { Program activities and application continued to be used in the } \\
\text { control group. The Entrepreneurship Perception in Science } \\
\text { Education Scale was used as the data collection tool in the study. } \\
\text { The scale was developed in order to determine secondary school } \\
\text { students' entrepreneurship perceptions. The scale consists of } 5 \\
\text { factors and } 28 \text { items. Findings of research indicated a significant } \\
\text { score difference in favor of the experiment group. In addition, } \\
\text { findings of sub-factor scores also indicated significant score } \\
\text { differences in favor of the experiment group According to the } \\
\text { results of the study, socio-scientific argumentation method } \\
\text { positively affected the students' entrepreneurship perception. } \\
\text { Furthermore, results show that socio-scientific argumentation } \\
\text { method positively affected the students' self-esteem, innovation } \\
\text { perception and creativity, leadership and tendency to stand out, } \\
\text { social skills and group work, and risk taking tendency. Socio- } \\
\text { scientific argumentation method might also have influenced the } \\
\text { entrepreneurship characteristics which is a learning outcome for } \\
\text { students according to the } 2013 \text { and } 2018 \text { Turkish Science Education } \\
\text { Program. }\end{array}$} \\
\hline & \\
\hline & \\
\hline $\begin{array}{l}\text { Accepted: } \\
02.10 .2020\end{array}$ & \\
\hline \multirow{8}{*}{$\begin{array}{l}\text { Key words: } \\
\text { Science education, } \\
\text { Socio-scientific } \\
\text { argumentation, } \\
\text { entrepreneurship, } \\
\text { contemporary teaching } \\
\text { methods, } \\
\text { perception }\end{array}$} & \\
\hline & \\
\hline & \\
\hline & \\
\hline & \\
\hline & \\
\hline & \\
\hline & \\
\hline
\end{tabular}

*Correspondency: erkanozcan88@gmail.com 


\section{Introduction}

In the twenty-first century, it is seen that entrepreneurial features are considered as one of the most important skills for students and it is emphasized that each course can contribute to the development of entrepreneurial features (Drucker, 2014). During the process, while there was no data on the direct entrepreneurship education approaches in science education in Turkey until 2013, the entrepreneurship stood out as a significant feature in Science Education Curriculum in 2013 and 2018 (Ministry of Education, 2013; Ministry of Education, 2018).

The entrepreneurship in science education can be used as a tool to equip students with the necessary skills and competencies that provide support for students to be able to cope with unemployment. Additionally entrepreneurship has different purposes such as encouraging individuals to become successful entrepreneurs by equipping individuals with various knowledge, skills and increasing their motivation; enabling them to gain a different perspective to see opportunities; contributing to their transformation into more creative, confident and determined individuals via improving their opinions; helping them become socially responsible and employable citizens (Wickham, 2006). Considering purposes and benefits of entrepreneurship, it can be said that science classes are the courses that entrepreneurship perception and skills stand out. Therefore, taking science courses are important for students since these students' entrepreneurship perception will have an effect on their performances in science courses.

\section{Entrepreneurship}

Entrepreneurship owns an enhanced value and importance as it helps encourage creation, expansion and application of new ideas, create new industries, increase output in technology based sectors and create fast-developing sectors. Entrepreneurship introduces new technologies to society and in this way undiscovered or less used resources are brought to economy and production is increased. In addition, entrepreneurship education, which is increasingly preferred by educational institutes, has contributed greatly to the awareness and comprehension on entrepreneurship concept itself (Malecki, 2018). Since entrepreneurship is a current subject, it seems that mostly teacher views are studied and not an adequate number of studies about developing secondary school students' entrepreneurship skills found in education literature. In addition, we can say that especially variables such as course contents, activities, teaching designs, developing and practicing teaching modules are absent in current focus. In order to make philosophy of entrepreneurship education more comprehensive in schools, this concept should be introduced with materials which make it functional, because in various studies teachers indicate that they are having difficulties while finding methods and contents for promoting students' entrepreneurship skills (Eckhardt \& Shane, 2003; Greve \& Salaff, 2003; Timmons \& Spinelli, 2004).

Science education can be defined as a course in which entrepreneurship perception and entrepreneurship skills are important components. Thus, entrepreneurship perceptions of students might have effect on their performance in science courses and are important from this angle of view. Also, literature shows that there are several studies towards entrepreneurship perceptions in science education with various groups (Deveci, 2018; Köybaşı \& Dönmez, 2017; Mungule \& Van Vuuren, 2016) but not enough number of studies towards secondary school students' entrepreneurship perceptions exist. 


\section{Socio-scientific argumentation}

One of the teaching methods that can positively affect the entrepreneurship perception in science education is socio-scientific argumentation. (Sadler \& Donnelly, 2006) Socio-scientific argumentation is a teaching method that socio-scientific issues are integrated in an argumentation-based learning process (Sadler \& Zeidler, 2005). Socioscientific argumentation is included in 2013 and 2018 Science Education Curriculum and a teaching method that needs to be included in science courses (Ministry of Education, 2013; Ministry of Education 2018). The argumentation elements developed with the socio-scientific argumentation can be used in science courses (Patronis et al., 1999). Socio-scientific issues are generally loaded with values in terms of science and ethics, they can have an uncomfortable structure for scientists, teachers and students (Hughes, 2000). Sadler and Zeidler (2005) stated the characteristics of socio- scientific issues as:

- Socio-scientific issues have a scientific base and inherently possess controversy and contradiction.

- It is often discussed under the influence of political and social factors by the individuals who make up the society.

The controversial nature of socio-scientific issues is related to degree of uncertainty in many issues (Simonneaux, 2008). Complexity and inevitable ethical issues are inherent in socio-scientific issues. On the other hand, argumentation can be defined as the process of supporting and validating claims with data by providing reasons (Erduran \& JiménezAleixandre, 2008). An argumentation-based teaching approach can be further defined as an oral/written activity where students question their friends and their own models, use support, rationale and evidence (in accordance with scientists thinking system) to support their own models, and use refutation to reveal the faults of their friends' models (Toulmin, 1958).

The main aim of a science course is that students should be able to know themselves and their environment and as well gaining basic life skills and higher level thinking skills (Millar, 2008). Accordingly, science courses enable students to encounter problems closely related to daily life and help students to easily adapt to their environment and world by enabling them to be aware of daily life problems, to question these problems, and to produce solutions to these problems (Tal, \& Dierking, 2014). However, students' entrepreneurship skills in inquiry and discussion entails further development. For this reason, the teaching methods that can improve students' inquiry and decision making skills should be referred to in science courses. In this way students can better express themselves and participate actively in the lessons (Kolodner, 2002) Thus using the socioscientific argumentation method, which includes not only social, political, economic, and moral dimensions but also scientific dimensions, will be effective (Sadler, 2011). For this reason, this study aimed to prepare guideline materials for using the argumentation method for socio-scientific issues and investigate this method's effectiveness on the students in terms of entrepreneurship perception. Therefore, effects of using socioscientific argumentation method on students' entrepreneurship perceptions in the secondary school science education course is examined.

\section{Method}

In the study quasi-experimental design with pretest-posttest control group, as one of the quantitative research, was used. In the quasi-experimental design with pretest- 
posttest control group, there is also a group which is not affected by the independent variables besides the experiment group which is affected by the independent variable (Gribbons \& Herman, 1996). In other words, this design includes an experiment and a control group. In this design, participants are not selected randomly. If there is not a significant difference between the pretest scores, relativel group equivalence can be used. While testing hypotheses, pretest and posttest scores should be compared to check if there is a significant difference (Büyüköztürk, 2008; Christensen, 2004). In this study whether there would be a difference in the entrepreneurial perceptions of the student group learning with the socio-scientific argumentation method and the student group learning with the science course curriculum and activities was investigated. Whilst socio-scientific argumentation method is an integral part of Science Education Curriculum and has to take part science courses (Ministry of Education, 2018), this study examines the effects of this method on a whole unit. Thusly, students learning with the socio-scientific argumentation method was chosen as the experiment group and students learning with the Science Education Curriculum and activities was chosen as the control group.

Table 1. Symbolic representation of the research pattern

\begin{tabular}{lll}
\hline & \multicolumn{1}{c}{ Experiment Group } & \multicolumn{1}{c}{ Control Group } \\
\hline 1.Step - Pre test & Perception Scale for & Perception Scale for \\
& Entrepreneurship & Entrepreneurship \\
\hline 2.Step- Practice & Socio-Scientific Argumentation & Science Course Curriculum and \\
& Method & Activities \\
\hline 3.Step- Post test & Perception Scale for Entrepreneurship & $\begin{array}{l}\text { Perception Scale for } \\
\text { Entrepreneurship }\end{array}$ \\
\hline
\end{tabular}

\section{Study Group}

Since the study owns a quasi-experimental design, an appropriate sampling method was resorted to and study group formed for the experimental practice. In experimental studies, it is preferable to choose a study group instead of selecting a population and sample. This is due to the fact that experimental studies generalizability to the universe is lower than descriptive studies (Sönmez, 2005).

The study took place in spring semester of the 2017-2018 academic year. Experiment and control groups were formed from students who were studying in four classes in a determined middle school in the 2017-2018 academic year. School selection was dependent upon the school's condition, which was taken into account in relation to the existence of computers and internet for collecting data during the application of socioscientific argumentation method from students. Four classes were specified as the study group, two classes were formed as the experiment group and the other two constituted the control group. Classes were randomly assigned as experiment groups and control groups. Additionally, during the experimental practice two teachers were selected to teach the lessons. One of the teachers was female (teacher A) and other teacher was male (teacher B). None of the teachers were conducting courses with four science classes prior to the current study, therefore two teachers were selected in order to keep students' level of readiness at a constant level. For teacher selection purposes, teachers' ability to apply innovative teaching methods and their experience in the practice of inquiry-based teaching which is highlighted in the Science Education Curriculum were taken into consideration. Both teachers have approximately 5 years of teaching experience. Both teachers were assigned an experiment group and a control group during the experimental practice. Teacher A had 23 students (10 Female, 13 male) in the experiment group and 
20 students (11 female, 9 male) in the control group. Teacher B had 22 students (12 female, 10 male) in the experiment group and 20 students (12 female, 8 male) in the control group.

\section{Preparation of the activities used in the research}

In the study while the lessons were taught with the socio-scientific argumentation method in the experiment group, Turkish Science Education Program activities and application continued to be used in the control group which includes inquiry based learning method, problem based group work approach and cooperative learning (Ministry of Education, 2018). During the experimental application, all the activities used in the experiment group were designed for the socio-scientific argumentation method. The study was carried out in the "Human and Environmental Relations" unit in the 7th grade science course. The unit includes "Ecosystems" and "Biodiversity" topics. Considering the course hours devoted to this unit, in the study experimental application was carried out for 16 hours as 8 hours for "ecosystem" and 8 hours for "biodiversity".

In the socio-scientific argumentation method the activities, which are based on a scenario with a socio-scientific issue, and the argumentation process, which is based on different ideas on the scenario, should be highlighted (Sadler, 2011). Three activity modules were developed in the study. In each module a socio-scientific issue related scenario was chosen from daily life events. Socio-scientific issue related scenarios were created in a clear and understandable way that include scientific and social elements and attract students' attention and involve them in the process. Thus there are four fictional views that are prepared to be passed to students via group discussion, in which students learn topics together in groups, switch groups and teach their topic to their new groups, based on this scenario. These views include as many opposite and divergent views as possible, and argumentation sections formed to turn the arguments expected from these views into arguments. A sample socio-scientific issue based scenario is given below (Özcan, 2019).

Conservation action plan required for "Dormouse" ( Myomimus roachi), which is one of the most rare rodent species living on earth.

Dormouse, which feeds with plants, fruits, seeds and insect larva, has a chunky body. Color of the upper side of the Dormouse's body is gray, while lower side is off-white. Ears are small and round-shaped. Unlike other mice, Dormouse has milk teeth. Owls, weasels, martens, wild cats, and snakes are the main hunters of these species.

Living in small populations in Trakya region and the area around, Dormouse species lost almost all of their natural living environments as a result of intense agriculture and forestry activities. Last members of these species are living in old oak, wild pear, walnut, almond trees and bushes situated amongst agriculture fields. Conservation action plan for these species has to be determined urgently and should last as long as it can be.

Turkish Ministry of Nutrition, Agriculture and Farming prepared a meeting in order to discuss the upcoming conservation action plan in order to protect the endangered species. The main topic of the meeting is to prepare a conservation action plan in order to protect the species and to discuss how this is going to affect various classes and business. Hence, environment experts are invited to Ministry's meeting. In addition, representatives of World Nature Conservation Foundation (WNCF), Trakya Farmers' Union (TFU), Foresty and Agriculture Business Foundation (FABF) and Turkish Scientist Foundation (TSF) are invited in order to learn about their views. 
In the meeting environment experts are going to listen to the views of different parties, voice their own opinions and then discuss the situation of Dormouse species and the ways through which they can be protected. Parties attending the meeting are going to express their views according to their aims and visions. Environment experts will discuss the situation of Dormouse after listening to these various views.

The modules based on the unit topics were designed and created separately for students and teachers. In the teacher module, different from the student module, there are instructions, related learning outcomes, and all the determined opinions. The modules for the experimental application were consulted to the opinion of the expert researchers. Additionally, since the socio-scientific argumentation method was applied in a biology unit, the opinion of a biology expert was consulted. According to the feedback received from the experts, the appropriate modifications in the activity modules were made and modules were prepared for the experimental application. In the last stage, activity modules were presented to teachers and 7th grade students in two different schools and their feedback on comprehensibility and student inclusion were obtained. Based on the feedback from teachers and students, the activity modules were finalized. The finalized activity module was implemented as a pilot in a 7th grade class who was not presented with "living beings and life" unit. The 7th grade class was in one of the schools whose teachers and students provided feedback. Thereupon, this pilot study helped to prepare for identifying possible problems that may occur in the experimental practice and with taking necessary precautions for these problems.

After the expert opinion and pilot implementation, a total of three activity modules on "Ecosystems" and "Biodiversity" topics in the "Human and Environment" unit were prepared for the experimental group students during the application. The modules consist of scenarios based on socio-scientific issues, learning instructions, and argumentation stages. Lesson plans for activity modules were prepared in order to help teachers during the experimental application process. During the experimental practice, both teachers taught in one experiment and one control group. Prior to the experimental practice, a twoday workshop with science teachers, who taught the course, was held on argumentation and socio-scientific issues.

\section{Data Collection Tools}

The Entrepreneurship Perception in Science Education Scale used in the study was developed by Özcan (2019). The scale was developed in order to determine secondary school students' entrepreneurship perceptions. The scale consists of 5 factors and 28 items. Factors of the scale are "self-esteem" (5 items), "innovation perception and creativity" (6 items), "leadership and tendency to stand out" (6 items), "social skills and group work" (6 items), and "risk taking tendency" (5 items). The scale consists of 21 positive and 7 negative items. Pilot study of the scale was conducted by applying to 1100 sixth, seventh, and eighth grade students at randomly determined 7 different secondary schools in İzmir. Half of the data collected was used for exploratory factor analysis and the other half was used for confirmatory factor analysis of the scale. The scale was prepared as likert type and the items were scored from 5 to 1 with the options "Totally agree: 5", "Agree: 4", "Indecisive: 3", "Disagree: 2", and "Totally disagree: 1". Maximum possible score can be taken from the scale is 140, while the minimum is 28 . Based on the scale's target group and pilot study participants, the very scale is suitable for $6^{\text {th }}, 7^{\text {th }}$ and $8^{\text {th }}$ grade secondary school students in its original form. 


\section{Experimental Practice}

In the experiment group lessons were taught with the socio-scientific argumentation method, and in the control group they were taught with the Science Education Curriculum and its activities. The experimental practice was limited to six weeks. With the applications of pretest and posttest, the whole practice took eight weeks in total.

During the experimental practice, in experiment group, socio-scientific argumentation activities formed towards the learning outcomes of "Living Beings and Life" unit, which is the 5th unit of the 7th grade in the 2013 Science Education Curriculum. Considering that there are four different views in the socio-scientific issues based scenarios in the activities, and due to the learning instructions, each student in the group was expected to learn about an opinion and narrate it to their group friends (Rose, 1991). Students are divided into groups of four-five people due to varying class sizes i.e. between 20-23 students. Each student in the groups left their original groups and brought into a new group with their peers to learn about an opinion with the new group members. After reading the opinions of the new group and discussing the strengths and weaknesses of the opinion with the peers in the new group, the students returned to their original groups, and narrated the opinion to their original group members. Then, students in the original group determined their common opinions after learning about different opinions from each group. Later on in the process, they created their arguments and carried out the argumentation phase.

\section{Data analysis}

In the study, data collected through pretest and posttest and they were analysed using appropriate statistical methods. SPSS program was used in the analysis of the data. Statistics test used to analyse data can be categorized as non-parametric and parametric tests. Parametric tests are based on the assumption that the sample of the research carries some of the features of the research universe, and mostly parametric tests can be used if the sample has certain features (Coolican, 2017). In order to use the parametric test analysis in analysing the data of the study, the data should be appropriate with the normal distribution (Blalock, 2017), which is the most critical continuous distribution. In addition, the variance of the scores should be homogeny (Ary et al., 2018). Shapiro-Wilks and Kolmogorov-Smirnov statistical tests are used to understand whether the data is appropriate for normal distribution (Razali \& Wah, 2011). If these two tests differ significantly at the level of .05 , it can be stated that the distribution of the data is significantly different from the normal distribution (Ghasemi \& Zahediasl, 2012). Therefore, the appropriateness of the data to normal distribution was tested by ShapiroWilks and Kolmogorov-Smirnov tests so as to determine the appropriate statistical method which needs to be used for the analysis of data obtained before and after the experimental process. As a result, students' pretest and posttest scores of the Entrepreneurship Perception in Science Education Scale and the questions related to daily life were appropriate for normal distribution. Thus, t-test, ANOVA, and/or ANCOVA tests were used to compare the students' score from the Entrepreneurship Perception in Science Education Scale $(\mathrm{p}<.05)$ 


\section{Findings}

In this part, findings on the collected data and comments on the findings are presented. In the analysis of findings, parametric statistical techniques were preferred due to the sufficient number of data, the distribution and histogram graphs showing the similar characteristics with the normal distribution, and the result of shapiro-wilks test did not significantly differ from the normal distribution. To this end, parametric tests were used to compare groups' scores from the Entrepreneurship Perception in Science Education Scale. Pretest t-test results of experiment and control group are shown in table 2.

Table 2. T-test test results regarding the comparison of the groups' pretest perceptions of entrepreneurship in science education

\begin{tabular}{lllllll}
\hline Groups & $\mathrm{N}$ & Rank Average & F & df & t & P \\
\hline Experiment group & 45 & 103.44 & 6.117 & \multirow{2}{*}{81} & \multirow{2}{*}{.995} & .323 \\
\hline Control group & 40 & 101.51 & & & \\
\hline
\end{tabular}

According to t-test results, there was no significant difference between the pretests of the entrepreneurship perception scores of the experimental and control group $(p=.323)$. Whence, even though there is no significant difference between the pretest scores of variables, there is a difference between the mean scores. For this reason, with a view to balancing the possible difference of the pretests, it is decided to assign covariant and thus to use ANCOVA in the analysis of participant's data. In addition, to be able to evaluate the socio-scientific argumentation's effect on the dependent variables free from independent variables, the effect value (partial eta square) calculation is included. Based on the first analysis results, data had equivalent covariance matrices and error variances according to the Box's $M$ test and Levene test results $(\mathrm{p}>.01)$. Thence, by continuing the analysis, the effect of independent variable on the dependent variable was tested using ANCOVA.

The Entrepreneurship Perception in Science Education Scale, which was applied to students, consists of five factors: "self-esteem", "innovation perception and creativity", "leadership and tendency to stand out", "social skills and group work", and "risk taking tendency". T-test was applied to pretest scores for each factor. In order to determine the pretest mean scores of students in the experiment and control group in the sub-factors of the Entrepreneurship Perception in Science Education Scale, t-test was applied. Table 3 shows the average scores of the students, in the experiment and control group, and t-test analysis results from the sub-factors of Entrepreneurship Perception in Science Education Scale applied after the experimental practice.

Table 3. T-test results regarding the comparison of the groups' pretest scores of Entrepreneurship Perception in Science Education Scale sub-factors.

\begin{tabular}{|c|c|c|c|c|c|}
\hline Sub-factor & Groups & $\mathrm{N}$ & Rank Average & $\mathrm{T}$ & $\mathrm{P}$ \\
\hline \multirow{2}{*}{ Self-esteem } & Experiment grp & 45 & 16.53 & \multirow{2}{*}{.283} & \multirow{2}{*}{.777} \\
\hline & Control group & 40 & 16.32 & & \\
\hline \multirow{2}{*}{$\begin{array}{l}\text { Innovation perception and } \\
\text { creativity }\end{array}$} & Experiment grp & 45 & 19.09 & \multirow{2}{*}{-.040} & \multirow{2}{*}{.968} \\
\hline & Control group & 40 & 19.12 & & \\
\hline \multirow{2}{*}{ Tendency to stand out } & Experiment grp & 45 & 24.75 & \multirow{2}{*}{-.835} & \multirow{2}{*}{.406} \\
\hline & Control group & 40 & 23.93 & & \\
\hline \multirow[b]{2}{*}{ Social skills and group work } & Experiment grp & 45 & 25.27 & \multirow{2}{*}{-.437} & \multirow[b]{2}{*}{.664} \\
\hline & Control group & 40 & 25.40 & & \\
\hline \multirow{2}{*}{ Risk taking tendency } & Experiment grp & 45 & 23.04 & \multirow{2}{*}{1.761} & \multirow{2}{*}{.082} \\
\hline & Control group & 40 & 21.70 & & \\
\hline
\end{tabular}


According to t-test results in table 3, there is no statistically significant difference between experiment and control group for comparing the scores: self-esteem, innovation perception and creativity, leadership and tendency to stand out, social skills and group work and risk taking tendency. With that being sad, there are differences between the averages. Thus, when comparing the posttest scores of the sub-factors, it was decided to apply the ANCOVA test by assigning covariants to equalize the mean differences between the pretests.

Table 4 shows the average scores of the students, in the experiment and control group, and ANCOVA test analysis results from the Entrepreneurship Perception in Science Education Scale applied after the experimental practice.

Table 4. ANCOVA test results regarding the comparison of the groups' posttest perceptions of entrepreneurship in science education

\begin{tabular}{llllll}
\hline Groups & $\mathrm{N}$ & Rank Average & $\mathrm{F}$ & $\mathrm{P}$ & Eta Squared \\
\hline Experiment group & 45 & 114.23 & & & \\
\hline Control group & 40 & 109.82 & & & \\
& & & & & \\
\end{tabular}

According to the analysis results, the posttest mean scores of the Entrepreneurship Perception in Science Education Scale were significantly different and this difference was in favor of the experiment group. $(\mathrm{F}=9.76, \mathrm{p}=.002, \eta \mathrm{p} 2=.107)$. In light of the results, the socio-scientific argumentation applications cause a significant difference on students' entrepreneurial perceptions.

To be able to determine the posttest mean scores of students in the experiment and control group in the sub-factors of the Entrepreneurship Perception in Science Education Scale, ANCOVA test was applied. Table 5 shows the average scores of the students, in the experiment and control group, and ANCOVA test analysis results from the sub-factors of Entrepreneurship Perception in Science Education Scale applied after the experimental practice.

Table 5. ANCOVA test results regarding the comparison of the groups' posttest scores of Entrepreneurship Perception in Science Education Scale sub-factors.

\begin{tabular}{|c|c|c|c|c|c|c|}
\hline Sub-factor & Groups & $\mathrm{N}$ & $\begin{array}{l}\text { Rank } \\
\text { Average }\end{array}$ & $\mathrm{F}$ & $\mathrm{P}$ & $\begin{array}{l}\text { Eta } \\
\text { Squared }\end{array}$ \\
\hline \multirow{2}{*}{ Self-esteem } & Experiment grp & 45 & 18.44 & \multirow{2}{*}{7.484} & \multirow{2}{*}{.001} & \multirow{2}{*}{.158} \\
\hline & Control group & 40 & 17.15 & & & \\
\hline \multirow{2}{*}{$\begin{array}{l}\text { Innovation perception } \\
\text { and creativity }\end{array}$} & Experiment grp & 45 & 19.32 & \multirow{2}{*}{4.544} & \multirow{2}{*}{.015} & \multirow{2}{*}{.103} \\
\hline & Control group & 40 & 18.18 & & & \\
\hline \multirow{2}{*}{ Tendency to stand out } & Experiment grp & 45 & 18.54 & \multirow{2}{*}{5.672} & \multirow{2}{*}{.003} & \multirow{2}{*}{.128} \\
\hline & Control group & 40 & 17.38 & & & \\
\hline \multirow{2}{*}{$\begin{array}{l}\text { Social skills and group } \\
\text { work }\end{array}$} & Experiment grp & 45 & 19.38 & \multirow{2}{*}{4.652} & \multirow{2}{*}{.012} & \multirow{2}{*}{.109} \\
\hline & Control group & 40 & 18.44 & & & \\
\hline \multirow{2}{*}{ Risk taking tendency } & Experiment grp & 45 & 23.04 & \multirow{2}{*}{4.113} & \multirow{2}{*}{.020} & \multirow{2}{*}{.101} \\
\hline & Control group & 40 & 21.70 & & & \\
\hline
\end{tabular}

Findings in table 5 indicate significant differences in the results of the ANCOVA tests that are applied to students in the experiment and control groups comparing the posttest entrepreneurship perception sub-factor scores. There is a statistically significant difference in favor of the experiment group in posttest self-esteem, innovation perception and creativity, leadership and tendency to stand out, social skills and group work factor 
and risk taking tendency factor scores of the groups.

\section{Conclusion, Discussion and Suggestions}

According to the data analysis results, there was no significant difference between the experiment group students and the control group students in terms of the pretest. Additionally, according to the result of analyses conducted separately for the five factors of the scale, there was no significant difference between student groups in terms of selfesteem, innovation perception and creativity, leadership and tendency to stand out, social skills and group work, and risk taking tendency. This result showed that prior to application, students groups were equivalent in terms of the Entrepreneurship Perception in Science Education and its sub-dimensions. Thereupon, it can be claimed that in order to determine the effect of the socio-scientific argumentation method in Entrepreneurship Perception in Science Education, the experiment and control groups which are not different from each other, are included in the research.

As a result of the data analysis, there was a significant difference between the experiment groups and the control groups in terms of the corrected posttest average scores of the Entrepreneurship Perception in Science Education Scale. When the comparative statistical results between the groups are examined, there is a statistical difference, in favor of the experiment group, between the experiment groups where the socio-scientific argumentation method was applied and the control groups where the science curriculum activities were applied. The study results showed that during the experimental practice, students' perceptions of the entrepreneurship in the experiment groups develop more than the students in the control groups. According to this result, the use of socio-scientific argumentation method in science classes positively contributes to the development of students' perception of entrepreneurship. There are studies also supporting that socioscientific issues and socio-scientific argumentation methods have a positive impact on the students' entrepreneurship perceptions in the literature (Çiftçi, 2016; Evren \& Kaptan, 2014; Kaya et al., 2015). Hence it can be argued that study results are parallel to the results in the literature. According to the findings, socio-scientific argumentation method positively affected the students' entrepreneurship perception. This method may also have influenced the entrepreneurship characteristics which is a learning outcome for students according to the 2013 and 2018 science curriculum. It can be claimed that the preparation and the structure of the socio-scientific argumentation activities used in the study are aimed to encourage students to take initiatives, put themselves forward, engage in group work, and take risks during the discussions as part of varying interaction patterns viz. as individuals and in the groups. It can be claimed that as a result of the analysis, there was a significant difference, in favor of the experiment group, in terms of the Entrepreneurship Perception in Science Education Scale for the secondary school students.

Entrepreneurship is a skill expected to be gained by middle school students in Turkey. The entrepreneurship skill as a learning outcome that is expected to be gained by students is included in the study as it expresses an individual's ability to transform their thoughts into action. Besides creativity, innovation, and risk taking, it also includes the ability to plan and manage projects in order to achieve goals in the Science Education Curriculum (Mcmullan \& Long 1987). This competence supports everyone not only at home or in the community, but also in business life so that they can be aware of the context and conditions of their work and seize business opportunities. It also provides a basis for more specific knowledge and skills needed by people taking part in or contributing to social 
and business activities. in Science Education Curriculum (Ministry of Education, 2018). Based on this statement and necessity, entrepreneurship should be prioritized in science class and it is one of the primary competencies that students should gain. Therefore, in order to have entrepreneurship competency for a student at the middle school level, they should be raised as an individual who has self-esteem, who is innovative and creative, has tendency to stand out, owns social skills, is open to group work, and posseses a tendency to take risks (Fredua-Kwarteng, 2005; Tsakiridou \& Stergiou, 2012).

Socio-scientific argumentation provides a learning environment in which students set out their own views and stances based on a socio-scientific issue, and support their arguments with the argument components and refute the arguments against it (Sadler, et al., 2017). In addition, socio-scientific argumentation creates a learning environment where students are able to reveal their individual original views and organize research to be able to access information on their own and to use this information in a discussion in order to transform it into an argument (Albe, 2008). In socio-scientific argumentation management, the socio-scientific issue stage reveals the student's perceptions of creativity and innovation in determining their own decision (Laius \& Rannikmae, 2011), while the argumentation stage reveals motivation, by nature, and self-esteem along with taking risks when necessary (Cronqvist \& Nyström, 2007). According to this, the socio-scientific argumentation activities that were applied in this study can support the entrepreneurship skills which are expected to be gained by the 7th grade students who were participants of the study. This might have caused the positive change on students' entrepreneurship perceptions.

Considering the socio-scientific argumentation method that was used in this study and the other factors in the activities can reveal the skills for middle school students to be able to have entrepreneurship skills. Arguably the activities applied to the experiment groups during the application of the study positively affected the students' entrepreneurship perceptions in science education. Therefore, during the learning process of the students in the experiment groups, the activities based on socio-scientific argumentation method and lessons with those activities affected students' entrepreneurship perceptions in a positive manner, which are related to the obtained results in this research.

\section{Suggestions}

In line with the findings and results, in this part of the study, suggestions for possible applications and possible new research areas regarding socio-scientific argumentation method are presented.

- According to the study results, for the most efficient usage of the socio-scientific argumentation method, and to be able to be helpful for students who are in the grade levels that include science classes, socio-scientific argumentation method based activity modules can be included in textbooks or resource books.

- Research should be conducted to investigate the effects of the use of socioscientific argumentation method in science education course on different variables such as students' high end thinking skills, conceptual understanding levels, and academic achievements.

- This study investigated the effect of socio-scientific argumentation method on the entrepreneurship perception in science education, but not on its effects on students' entrepreneurship. In the future research, it is thought that the effect of 
the method can be determined by creating a data collection tool in order to determine the entrepreneurship in science education for middle school students.

- The effect of socio-scientific argumentation on the entrepreneurship perceptions in science class was carried out with the seventh grade students in a single school. In the future studies, other variables can be incorporated for different regions and with different sample groups.

\section{References}

Albe, V. (2008). When scientific knowledge, daily life experience, epistemological and social considerations intersect: Students' argumentation in group discussions on a socio-scientific issue. Research in Science Education, 38(1), 67-90.

Blalock, H. M. (2017). Measurement in the social sciences. Routledge.

Büyüköztürk, Ş., (2008). Scientific Research Methods. Ankara: Pegem Akademi.

Christensen, L. B. (2004). Experimental methodology. Allyn \& Bacon.

Çiftçi, A. (2016). Investigation of fifth, sixth and seventh grade students' argumentation quality in science lessons. Unpublished Master Thesis, Alpaslan University, Muş.

Coolican, H. (2017). Research methods and statistics in psychology. Psychology Press.

Cronqvist, A., \& Nyström, M. (2007). A theoretical argumentation on the consequences of moral stress. Journal of Nursing Management, 15(4), 458-465.

Deveci, İ. (2018). Investigation of science-based entrepreneurial tendencies of middle school students. Journal of Science, Mathematics, Entrepreneurship and Technology Education, 1(1), 19-47.

Drucker, P. (2014). Innovation and entrepreneurship. Routledge.

Eckhardt, J. T., \& Shane, S. A. (2003). Opportunities and entrepreneurship. Journal of management, 29(3), 333-349.

Erduran, S., \& Jiménez-Aleixandre, M. P. (2008). Argumentation in science education. Dordrecht: Springer.

Evren, A., \& Kaptan, F. (2014). Importance of socioscientific issue based teaching in science education. EAB 2012 VI. International Congress of Educational Research, 389-402.

Fredua-Kwarteng, E. (2005). Enhancing secondary education in Ghana: The case of entrepreneurship. Online Submission.

Ghasemi, A., \& Zahediasl, S. (2012). Normality tests for statistical analysis: a guide for non-statisticians. International journal of endocrinology and metabolism, 10(2), 486.

Greve, A., \& Salaff, J. W. (2003). Social networks and entrepreneurship. Entrepreneurship theory and practice, 28(1), 1-22.

Gribbons, B., \& Herman, J. (1996). True and quasi-experimental designs. Practical assessment, research, and evaluation, 5(1), 14.

Hughes, G. (2000). Marginalization of socioscientific material in science-technologysociety science curricula: Some implications for gender inclusivity and curriculum reform. Journal of Research in Science Teaching, 37, 426-440.

Kolodner, J. L. (2002). Facilitating the learning of design practices: Lessons learned from an inquiry into science education. Journal of Industrial Teacher Education, 39(3), 9-40.

Köybaş1, F., \& Dönmez, B. (2017). The analysis of school principals' perception of entrepreneurship, self-efficacy and organizational commitment. Educational Administration: Theory and Practice, 23(2), 249-280. 
Laius, A., \& Rannikmäe, M. (2011). Impact on student change in scientific creativity and socio-scientific reasoning skills from teacher collaboration and gains from professional in-service. Journal of Baltic Science Education, 10(2).

Malecki, E. J. (2018). Entrepreneurship and entrepreneurial ecosystems. Geography Compass, 12(3), 1259.

Mcmullan, W. E., \& Long, W. A. (1987). Entrepreneurship education in the nineties. Journal of Business Venturing, 2(3), 261-275.

Millar, R. (2008). Taking scientific literacy seriously as a curriculum aim. Asia-Pacific Forum on Science Learning and Teaching, 9(2), 1-18.

Ministry of Education, (2013). Middle school science education course program $\left(3^{\text {rd }}, 4^{\text {th }}\right.$, $5^{\text {th }}, 6^{\text {th }} 7^{\text {th }}$ and $8^{\text {th }}$ grades). Ankara: Government Books Publication Department.

Ministry of Education, (2018). Middle school science education course program. Ankara: Government Books Publication Department.

Mungule, C. M., \& Van Vuuren, J. J. (2016). Validating a measurement scale for entrepreneurial actions for sustainable corporate entrepreneurship using confirmatory factor analysis. Acta Commercii, 16(1), 1-15.

Özcan, E. (2019). The effects of socio-scientific argumentation method on students' levels of relating knowledge with daily life, enterpreneurship and attitudes towards sustainable science. Unpublished PhD Thesis, Dokuz Eylül University, İzmir.

Patronis T., Potari D. \& Spiliotopoulou V., (1999). Students' argumentation in decisionmaking on a socio-scientific issue: implications for teaching. International Journal of Science Education, 21(7), 745- 75.

Razali, N. M., \& Wah, Y. B. (2011). Power comparisons of shapiro-wilk, kolmogorovsmirnov, lilliefors and anderson-darling tests. Journal of statistical modeling and analytics, 2(1), 21-33.

Sadler, T. D. (2011). Socio-scientific issues in the classroom. Springer, Dordrecht.

Sadler, T. D., \& Donnelly, L. A. (2006). Socioscientific argumentation: The effects of content knowledge and morality. International Journal of Science Education, 28(12), 1463-1488.

Sadler, T. D., Foulk, J. A., \& Friedrichsen, P. J. (2017). Evolution of a model for socioscientific issue teaching and learning. International Journal of Education in Mathematics, Science and Technology, 5(2), 75-87.

Sadler, T. D. \& Zeidler, D. (2005). Patterns of informal reasoning in the context of socioscientific decision making. Journal of Research in Science Teaching 42(1), 112-138.

Simonneaux L., (2008). Argumentation in socio-scientific contexts. Edit (Erduran S, Jimenez- Aleixandre, M.P., Argumentation in Science Education. Springer.

Sönmez, V. (2005). Mistakes made in scientific researches. Eurasian Journal of Educational Research (EJER), (18).

Tal, T., \& Dierking, L. D. (2014). Learning science in everyday life. Journal of Research in Science Teaching, 51(3), 251-259.

Timmons, J. A., Spinelli, S., \& Tan, Y. (2004). New venture creation: Entrepreneurship for the 21st century (Vol. 6). New York: McGraw-Hill/Irwin.

Toulmin, S. E. (1958). The uses of argument. Cambridge. Cambridge University Press.

Tsakiridou, H., \& Stergiou, K. (2012). Entrepreneurship education in primary education departments. The case of the University of Western Macedonia in Greece. Proceedings in ARSA-Advanced Research in Scientific Areas, (1).

Wickham, P. A. (2006). Strategic entrepreneurship. Pearson Education. 